\title{
Fifteen Years Editorial
}

Phyllomedusa - Journal of Herpetology, the first Brazilian journal entirely dedicated to Herpetology, is publishing its $15^{\text {th }}$ volume in 2016. It was created in 2002 (with the subtitle Journal of Neotropical Herpetology), sponsored by Melopsittacus Publicações Científicas and partially supported by Universidade Federal de Minas Gerais; Melopsittacus was a publisher originally dedicated to the publication of scientific and semi-technical periodicals dealing with birds and headed by André Nemésio, an entomologist (!). Our original Editorial Board was composed of Renato Neves Feio and André Nemésio, as Associate Editors, and by 26 of the most renowned herpetologists, mainly from Brazil. Since 2004 Phyllomedusa has been published and primarily supported by Universidade de São Paulo (USP).

The journal had its geographical scope widened and adopted English as its only language in 2007, when we greatly expanded the board of Associate Editors to include herpetologists from Brazil (8), USA (6), Argentina (3), Australia (2), Canada (2), Belgium (1), France (1), Germany (1), Italy (1), Spain (1), and the United Kingdom (1). Linda Trueb is our Senior Associate Editor. Today the board members are herpetologists from Brazil (18), USA (4), Argentina (2), Austria (1), Mexico (1), and Canada (1).

In 2015 Phyllomedusa was indexed in the Web of Science, and in June 2016 we obtained our first impact factor (JCR - Journal of Citation Reports: 0.185 for 2015).

Including the papers in the present issue, we have published 147 articles, 59 short communications, 20 book reviews, four editorials, and (unfortunately) five obituaries. Distribution of articles and short communications among taxa is as follows: Anura (50.5\%), Caudata (1.9\%), Gymnophiona (0.5\%), Crocodylia (1\%), Testudines (2.9\%), lizards (20.9\%), Amphisbaenia (1.5\%), Serpentes (18.9\%), and herpetofauna $(1.9 \%)$. Papers have been roughly distributed in the following areas: taxonomysystematics (32\%), ecology (31\%), natural history-behavior (25\%), genetics (4\%), anatomy-physiology (4\%), and conservation (4\%). Taxa represented in publications are from 29 countries from South, Central and North America, Europe, Asia and Oceania.

We have also contributed significantly toward enhancing the knowledge of worldwide amphibian and reptile biodiversity by means of the original description of 31 new species, including 15 anurans, seven lizards, two amphisbaenians, and seven snakes (Table 1, Figure 1).

My sincere acknowledgments go to all authors, referees, associate editors, members of the editorial board, subscribers, readers, and other contributors from the herpetological community around the world, who wrote, reviewed, read, and cited papers. Your efforts have supported PHYLLOMEDUSA on its relatively long journey to international recognition. Special thanks must be given to André Nemésio (who conceived and produced PhyllomedusA in the first years), Idmar Pedro Silvério (who composed all 29 issues), Breck Bartholomew (who distributes the journal and accepts international subscriptions via ZenScientist, formerly Bibliomania!), Fábio Augusto Bazzanelli (our web designer and master), André Serradas (from SIBi-USP), Gerson O. Romão (who has helped me with numerous editorial tasks since 2014), and finally to Escola Superior de Agricultura Luiz de Queiroz - ESALQ-USP, to which our ISSN has belonged since 2004 and which has supported the journal since then.

Jaime Bertoluci Editor-in-Chief 
Table 1. New species of amphibians and reptiles originally described in Phyllomedusa. *See Figure 1.

\begin{tabular}{|c|c|c|}
\hline ANURANS & Country & Photo* \\
\hline Allobates algorei Barrio-Amorós and Santos, 2009 & Venezuela & 1 \\
\hline Colostethus granti Kok, MacCulloch, Gaucher, Poelman, Bourne, Lathrop and Lenglet 2006 & French Guiana & 2 \\
\hline Eleutherodactylus waoranii McCracken, Forstner and Dixon, 2007 & Ecuador & 3 \\
\hline Gastrotheca dysprosita Duellman, 2013 & Peru & 4 \\
\hline Mannophryne orellana Barrio-Amorós, Santos and Molina, 2010 & Venezuela & 5 \\
\hline Mannophryne urticans Barrio-Amorós, Santos and Molina, 2010 & Venezuela & 6 \\
\hline Mannophryne vulcano Barrio-Amorós, Santos and Molina, 2010 & Venezuela & 7 \\
\hline Melanophryniscus vilavelhensis Steinbach-Padilha, 2008 & Brazil & 8 \\
\hline Nyctimystes kuduki Richards, 2007 & Papua New Guinea & 9 \\
\hline Osteocephalus phasmatus MacCulloch and Lathrop, 2005 & Guyana & 10 \\
\hline Pristimantis adiastolus Duellman and Hedges, 2007 & Peru & 11 \\
\hline Pristimantis albertus Duellman and Hedges, 2007 & Peru & 12 \\
\hline Pristimantis minutulus Duellman and Hedges, 2007 & Peru & 13 \\
\hline Pristimantis gryllus Barrio-Amorós, Guayasamin and Hedges, 2012 & Venezuela & 14 \\
\hline Phrynopus lechriorhynchus Trueb and Lehr, 2008 & Peru & 15 \\
\hline
\end{tabular}

\section{AMPHISBAENIANS AND LIZARDS}

Amphisbaena arda Rodrigues, 2002

Amphisbaena ibijara Rodrigues, Andrade and Lima, 2003

$\begin{array}{cc}\text { Brazil } & 16 \\ \text { Brazil } & 17 \\ \text { Panama } & 18 \\ \text { Panama } & 19 \\ \text { Brazil } & 20 \\ \text { India } & 21 \\ \text { Paraguay } & 22 \\ \text { Chile } & 23 \\ \text { Brazil } & 24\end{array}$

Anolis ibanezi Poe, Latella, Ryan and Schaad, 2009

Anolis kunayalae Hulebak, Poe, Ibánez and Williams, 2007

Enyalius erythroceneus Rodrigues, Freitas, Silva and Bertolotto 2006

Eublepharis satpuraensis Mirza, Sanap, Raju, Gawai and Ghadekar, 2014

Homonota rupicola Cacciali, Ávila and Bauer, 2007

Phymaturus aguedae Troncoso-Palacios and Esquerré, 2014

Stenocercus sinesaccus Torres-Carvajal 2005

Brazil

\section{SNAKES}

Bothrops marmoratus Silva and Rodrigues, 2008

Clelia hussami Morato, Franco and Sanches, 2003

Helicops tapajonicus Frota, 2005

Micrurus tamaulipensis Lavin-Murcio and Dixon, 2004

Thamnodynastes almae Franco and Ferreira, 2002

Thamnodynastes lanei Bailey, Thomas and Silva, 2005

Thamnodynastes sertanejo Bailey, Thomas and Silva, 2005

$\begin{array}{ll}\text { Brazil } & 25 \\ \text { Brazil } & 26 \\ \text { Brazil } & 27 \\ \text { Mexico } & 28 \\ \text { Brazil } & 29 \\ \text { Brazil } & 30 \\ \text { Brazil } & 31\end{array}$



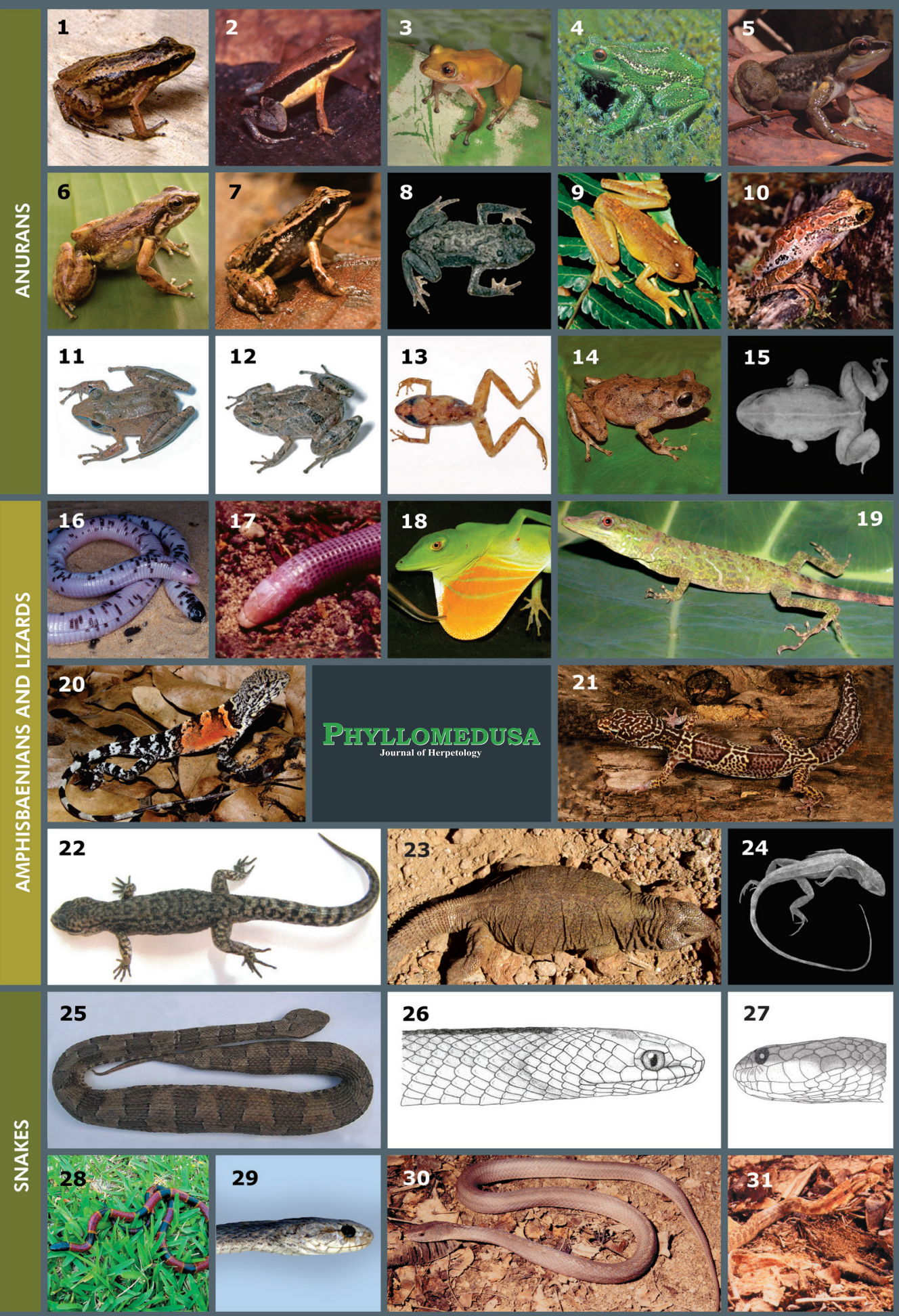

Figure 1. New species of amphibians and reptiles originally described in PhyLlomedusa (see Table 1). 


\section{References}

Bailey, J. R., R. A. Thomas, and N. J. Silva Jr. 2005. A revision of the South American snake genus Thamnodynastes Wagler, 1830 (Serpentes, Colubridae, Tachymenini). I. Two new species of Thamnodynastes from Central Brazil and adjacent areas, with a redefinition of and neotype designation for Thamnodynastes pallidus (Linnaeus, 1758). Phyllomedusa 4: 83-101.

Barrio-Amorós, C. L. and J. C. Santos. 2009. Description of a new Allobates (Anura, Dendrobatidae) from the eastern Andean piedmont, Venezuela. Phyllomedusa 8: 89-104.

Barrio-Amorós, C. L., J. M. Guayasamin, and S. B. Hedges, 2012. A new minute Andean Pristimantis (Anura: Strabomantidae) from Venezuela. Phyllomedusa 11: 83-93.

Barrio-Amorós, Santos, and Molina, 2010. An addition to the diversity of dendrobatid frogs in Venezuela: description of three new collared frogs (Anura: Dendrobatidae: Mannophryne). Phyllomedusa 9: 3-35.

Cacciali, P., I. Avila, and F. Bauer. 2007. A new species of Homonota (Squamata, Gekkonidae) from Paraguay, with a key to the genus. Phyllomedusa 6: 137-146.

Duellman, W. E. 2013. An elusive new species of Marsupial Frog (Anura: Hemiphractidae: Gastrotheca) from the Andes of northern Peru. Phyllomedusa 12: 3-11.

Duellman, W. E. and S. B. Hedges. 2007. Three new species of Pristimantis (Lissamphibia, Anura) from montane forests of the Cordillera Yanachaga in Central Peru. Phyllomedusa 6: 119-135.

Franco, F. L. and T. G. Ferreira. 2002. Descrição de uma nova espécie de Thamnodynastes Wagler, 1830 (Serpentes, Colubridae) do nordeste brasileiro, com comentários sobre o gênero. Phyllomedusa 1: 57-74.

Frota, J. G. 2005. Nova espécie de Helicops Wagler, 1830 (Serpentes, Colubridae) do rio Tapajós, Amazônia, Brasil. Phyllomedusa 4: 61-67.

Hulebak, E., S. Poe, R. Ibánez, and E. E. Williams. 2007. A striking new species of Anolis lizard (Squamata, Iguania) from Panama. Phyllomedusa 6: 5-10.

Kok, P. J. R., R. D. MacCulloch, P. Gaucher, E. H. Poelman, G. R. Bourne, A. Lathrop, and G. L. Lenglet. 2006. A new species of Colostethus (Anura, Dendrobatidae) from French Guiana with a redescription of Colostethus beebei (Noble, 1923) from its type locality. Phyllomedusa 5: 43-66.

Lavin-Murcio, P. A. and J. R. Dixon. 2004. A new species of coral snake (Serpentes, Elapidae) from the Sierra de Tamaulipas, Mexico. Phyllomedusa 3: 3-7.

MacCulloch, R. D. and A. Lathrop. 2005. Hylid frogs from Mount Ayanganna, Guyana: new species, redescriptions, and distributional records. Phyllomedusa 4: 17-37.
McCracken, S. F., M. R. J. Forstner, and J. R. Dixon, 2007 A new species of the Eleutherodactylus lacrimosus assemblage (Anura, Brachycephalidae) from the lowland rainforest canopy of Yasuni National Park, Amazonian Ecuador. Phyllomedusa 6: 23-35.

Mirza, Z. A., R. V. Sanap, D. Raju, A. Gawai, and P. Ghadekar. 2014. A new species of lizard of the genus Eublepharis (Squamata: Eublepharidae) from India. Phyllomedusa 13: 75-90.

Morato, S. A., F. L. Franco, E. J. and Sanches. 2003. Uma nova espécie de Clelia (Serpentes, Colubridae) do sul do Brasil. Phyllomedusa 2: 93-100.

Poe, S., I. M. Latella, M. J. Ryan, and E. W. Schaad. 2009. A new species of Anolis lizard (Squamata, Iguania) from Panama. Phyllomedusa 8: 81-87.

Richards, S. J. 2007. A new species of Nyctimystes (Anura, Hylidae) from Papua New Guinea and comments on poorly-known members of the genus. Phyllomedusa 6: 105-118.

Rodrigues, M. T. 2002. Herpetofauna of the Quaternary sand dunes of the Middle Rio São Francisco, Bahia, Brazil. VIII. Amphisbaena arda sp. nov., a fuliginosa-like checkered patterned Amphisbaena (Squamata, Amphisbaenidae). Phyllomedusa 1: 51-56.

Rodrigues, M. T., G. V. Andrade, and J. D. Lima. 2003. A new species of Amphisbaena (Squamata, Amphisbaenidae) from state of Maranhão, Brazil. Phyllomedusa 2: $21-26$.

Rodrigues, M. T., M. A. Freitas, T. F. S. Silva, and C. E. V. Bertolotto. 2006. A new species of lizard genus Enyalius (Squamata, Leiosauridae) from the highlands of Chapada Diamantina, state of Bahia, Brazil, with a key to species. Phyllomedusa 5: 11-24.

Silva, V. X. and M. T. Rodrigues. 2008. Taxonomic revision of the Bothrops neuwiedi complex (Serpentes, Viperidae) with description of a new species. Phyllomedusa 7: 4590.

Steinbach-Padilha, G. C. 2008. A new species of Melanophryniscus (Anura, Bufonidae) from the Campos Gerais region of Southern Brazil. Phyllomedusa 7: 99-108.

Torres-Carvajal, O. 2005 A new species of Stenocercus (Squamata, Iguania) from central-western Brazil with a key to Brazilian Stenocercus. Phyllomedusa 4: 123-132.

Troncoso-Palacios, J. and D. Esquerré. 2014. A new species of Phymaturus of the P. mallimaccii Group from the Andes of central Chile (Iguania: Liolaemidae). Phyllomedusa 13: 3-15.

Trueb, L. and E. Lehr. 2008. A new species of Phrynopus (Anura, Strabomantidae) from Peru, with comments on the osteology of the genus. Phyllomedusa 7: 11-24. 